\title{
定常条件下における一質点バイリニア型履歴系の床応答加速度に含まれる高調波成分 HIGHER HARMONICS OF FLOOR ACCELERATION IN SDOF SYSTEM
WITH BILINEAR HYSTERESIS UNDER PERIODIC SINUSOIDAL GROUND MOTION
}

\author{
金子 健 作*
}

Kensaku KANEKO

\begin{abstract}
This paper is a preliminary study to evaluate the seismic force of nonstructural components beyond the elastic limit of buildings. Floor responses involving higher harmonics are investigated in an SDOF system subjected to sinusoidal ground motion. In order to simplify the formulation, floor acceleration waveform is approximated using piecewise linear waveform in the steady state condition. A closed form of Fourier amplitude of the higher harmonics is formulated in terms of a post-yield stiffness ratio and a ductility factor. The solution is compared with the Fourier amplitude obtained by nonlinear time history analysis and confirmed to be reasonable.
\end{abstract}

Keywords : Floor response spectrum, Ceiling, Nonstructural component, Friction damper, Passive vibration control, Base-isolated building 床応答スペクトル, 天井, 非構造部材, 摩擦ダンパー, 制振建物, 免震建物

\section{1. はじめに}

2014 年 4 月に施行された「安全上重要である特定天井および特定 天井の構造耐力上安全な構造方法を定める件」(平成 25 年国土交通 省告示第 771 号) では, 中小地震の地震力に相当する水平震度を用 いて, 特定天井の主たる水平抵抗要素である斜め部材の短期許容応 力度設計を求めている ${ }^{1)}$ 。しかしながら，これにより設計された天 井が大地震時にどのような状態になり得るかは, 明確には示されて いない。その背後には, 保有水平耐力で決まる床応答加速度の上限 により, 大地震時の天井の地震力が安全率を含んだ許容応力度設計 時のそれを大きく上回らないという見込みがあると推測される。

建物が弾性である場合の床応答スペクトルの研究は, 古くからお こなわれているものの, 建物が弾塑性である場合の研究は少ない。 Lin and Mahin ${ }^{2}$ は, 複数の観測波による時刻歴解析を包絡する応答ス ペクトルの評価式を提案している。その後, Politopoulos and Feau ${ }^{3)}$ は, この応答スペクトルから逸脱する場合があることを指摘してい る。最近では, 特定天井の地震力評価の改善という視点からの佐藤・ 石原ら ${ }^{4)}$ の研究がある。いずれも, 設計に用いられることが意図さ れ, 多数の非線形時刻歴解析により得られる床応答スペクトル群を 包絡するなど経験的手法に基づいている。このような方針は, 実務 の設計に用いるには有効である。しかし, その一方で, 振動論に基 づいた理論的な床応答スペクトルを導出することも, 研究の発展の ために留まらず実務にも役立つであろう。なぜならば，建物の耐力 や剛性, 減衰をいかにして調整すれば, 天井等の非構造部材や天吊 り設備（以下，2 次系と称す）の地震被害を少なくできるかという 設計での意思決定に資するからである。制振建物や免震建物は, 特 にこの範疇である。著者は, 高減衰系を対象に含めた弾性建物につ
いて，時刻歴解析を介さずに，地震応答スペクトルから床応答スペ クトルを直接評価する手法を提案した ${ }^{5)}$ 。自然な流れとして，等価 線形化手法を援用した弾塑性問題への拡張が考えられるが，それに は一つ課題が残る。それは, 近似的な床応答スペクトルを与える等 価線形化した床応答加速度が存在し得るかということである（Fig. 1)。この問題を議論するには, 視座を変える必要がある。Caughey ${ }^{6}$, Jennings ${ }^{7}$ による等価線形化手法は，系の定常応答を slowly-varying で仮定したうえで，弾塑性系の定常応答の第 1 次近似（基本応答） の理論解を採用したものである。1 質点系の最大応答を求めるには, この 1 次近似で十分であることが多くの研究で確かめられている。 しかしながら，2 次系の入力となる床応答加速度を評価するには， 基本波以外の高調波と呼ばれる波の特性の理解が必要であろう。こ の高調波は，定常条件下での摩擦系については分析されているもの の ${ }^{8), 9)}$ ，一般的な弾塑性系については明らかにされていない。

以上より, 本論文では, 弾塑性建物の絶対加速度応答（床応答加 速度）の振動数成分を分析する。地震応答を分析する足掛かりとし て, 本報では, 調和地動を受ける 1 質点系の定常応答に限定し, こ

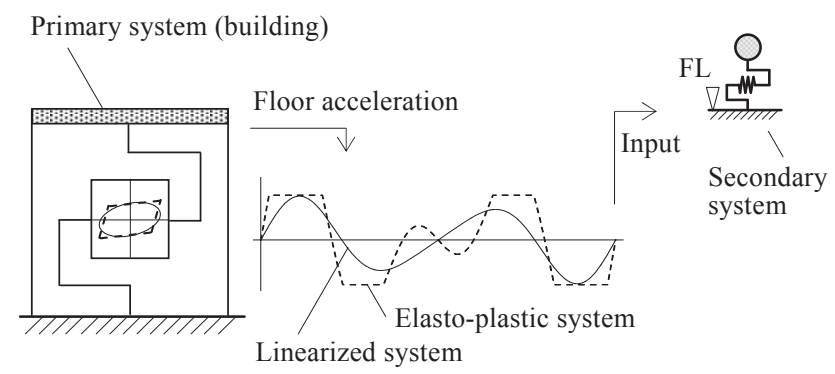

Fig. 1 Schematic illustration of two types of floor acceleration

$*$ 東京工業大学環境 $\cdot$ 社会理工学院建築学系 助教 $\cdot$ 博士 $($ 工学)

Assist. Prof., School of Environment and Society, Dept. of Architecture and Building Engineering, Tokyo Institute of Technology, Dr. Eng. 
の床応答加速度の周波数特性の閉解を導出する。これにより, 建物 の動特性と最大応答が高調波の発生に及ぼす影響を明確化する。な お, 定常応答下で 2 次系の最大応答を議論する意義は薄いため, 本 報では，いかにして高調波を簡易に評価するかに主眼を置く。

\section{2. 建物の履歴特性が 2 次系の応答に及ぼす影響}

\section{1 解析条件}

質量 $M$ を有する 1 質点系の建物の基部に調和地動 $\ddot{u}_{g}$ を受けたと きの問題を考える。建物の復元力 $Q$ の履歴特性は, 降伏耐力 $Q_{v}$ を 有するノーマルバイリニア型とする (Fig. 2)。初期剛性を $K$, 降伏 後の 2 次剛性を $p K$ と表し, $p$ を 2 次剛性比と呼称寸る。 $\omega$ を弾性 時の建物の固有円振動数とする。地盤面からの建物の相対変位を $u$ とし, 地動の作用開始から十分に経過した定常状態における建物の 最大変位を $\mu u_{y}$ で表す。ここで， $\mu$ は塑性率， $u_{y}$ は建物の降伏変位 である。建物の内部減衰は, 次のように考える。制振建物では, 架 構の剛性（1 質点系の降伏後の接線剛性）に比例して内部減衰を導 入するのが通例であり，以下の振動方程式を考える。

$$
M \ddot{u}+2 M h \sqrt{p} \omega \dot{u}+Q(u)=-M \ddot{u}_{g}
$$

ただし, 床応答加速度から高調波成分を抽出するうえでは, 粘性減 衰項の有無は, 本質的な問題ではない。そのため, 高調波を定式化 寸る段階では非減衰系 $(h=0)$ の建物に限定し, 第 5 章の時刻歴解析 による検証の段階で粘性減衰を導入する。

建物の質量に比して 2 次系の質量は極めて小さく, 慣性の相互作 用は生じないとする。この条件下で, 以下の振動方程式を考える。

$$
\ddot{u}_{a}+2 h_{a} \omega_{a} \dot{u}_{a}+\omega_{a}^{2} u_{a}=-\left(\ddot{u}_{g}+\ddot{u}\right)
$$

ここに， $\omega_{a}, h_{a}$ はそれぞれ 2 次系の固有円振動数および減衰定数で ある。 $u_{a}$ は, 建物からの 2 次系の相対変位である。

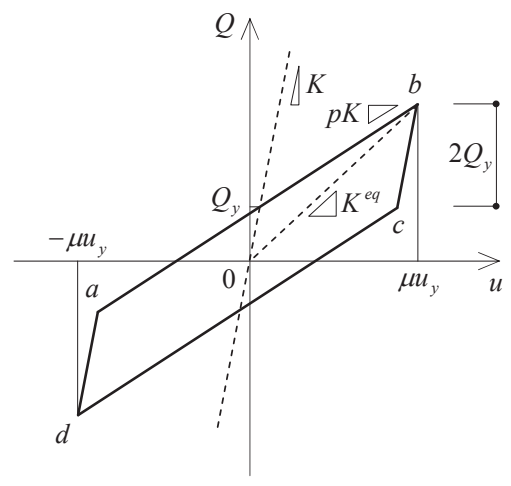

Fig. 2 Hysteresis rule of SDOF system with normal bilinear model

\subsection{2 次系の絶対加速度の時刻歴応答}

定式化に先立ち, 高調波の存在が認められる時刻歴応答解析の一 例を示すことにより，本論文で取り扱う主題を明確にする。この目 的のために, 次の $2 つ の$ 異なる系の床応答加速度を入力した場合の 2 次系の絶対加速度応答の違いを分析する。

- Case NL： 弹塑性系の床応答加速度を 2 次系に入力

- Case EL： 等価線形系の床応答加速度を 2 次系に入力 式(1)を解いた結果から得られる床応答加速度を用いる方法が Case NLである。Case EL では, Case NL の床応答加速度の最大值(ZPA)
を有する正弦波に置換する。

数值解析結果を整理する変数として, 以下で定義する 2 次系と建 物の振動数比 $\gamma$ を導入する。

$$
\gamma=\frac{T^{e q}}{T_{a}}
$$

ここで, $T_{a}$ は 2 次系の固有周期, $T^{e q}$ は建物の最大応答時の割線剛 性 $K^{e q}$ を用いた等価固有周期である。

一例として, $p=0.15, \mu=10$ および $h_{a}=0.02$ での, 2 次系の絶 対加速度応答の時刻歴を計算した結果が Fig. 3 である。定常状態を 対象としているため, ここで例示する振動数比 $\gamma$ を自然数に限定し た。 $\gamma$ が 1 や奇数以外の場合には, Case NL と Case EL の応答の差 は小さい。一方, $\gamma$ が奇数での両者の差は顕著である。この応答の 差は, 床応答加速度に含まれる高調波により励起される成分である。 この高調波を簡易に評価するための方法を以降で説明する。
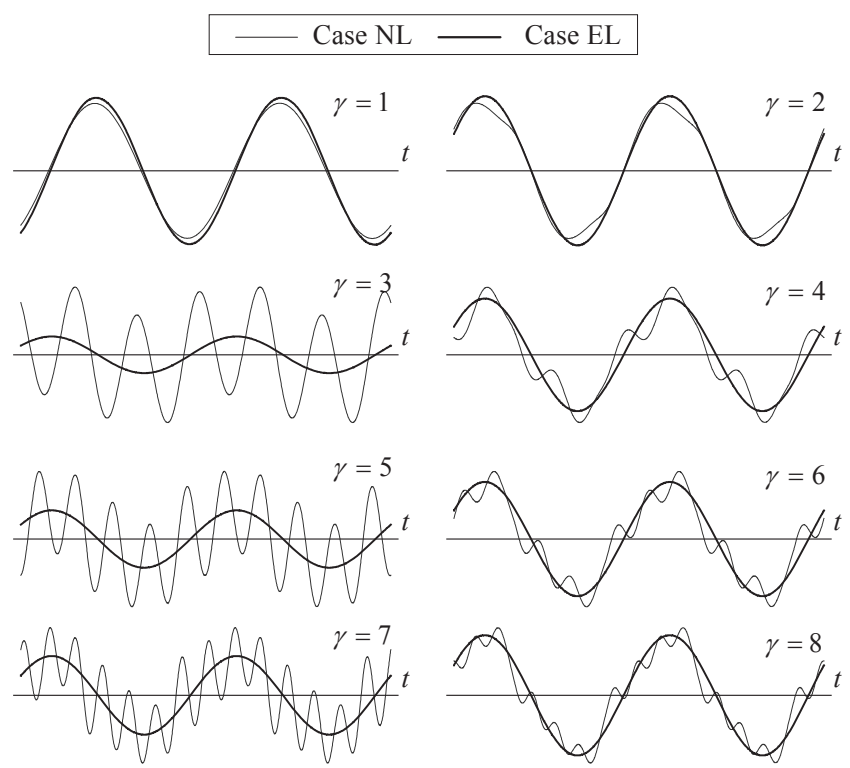

*All the amplitudes are normalized with respect to the case NL.

Fig. 3 Variation of acceleration responses of secondary system

\section{3. 床応答加速度の時刻歴の近似}

\section{1 多直線近似}

バイリニア型履歴系の定常応答には，1 サイクルの負荷状態に応 じて区分的に導出した微分方程式の厳密解 ${ }^{10)}$ がある。しかし，厳密 解を用いて, 本研究で関心がある床応答加速度の周波数特性の閉解 を導出するのは相当に煩雑である。本論文では，より平易な定常応 答の数式表現が必要であると考え, その導出法について述べる。 準備として, 建物の復元力 $Q$ を降伏耐力 $Q_{y}$ で無次元化する。

$$
\bar{Q}=\frac{Q}{Q_{y}}, \quad Q_{y}=\alpha_{y} M g
$$

ここに， $\alpha_{y}$ は建物の降伏せん断力係数， $g$ は重力加速度である。 定常状態における $\bar{Q}$ の最大值を $\bar{\alpha}$ とする。 $\bar{\alpha}$ は, その定義から, 2 次剛性比 $p$ と塑性率 $\mu$ を用いて, 以下のように算定できる。

$$
\bar{\alpha}=1+p(\mu-1)
$$

周期関数である $\bar{Q}$ の基本周期を $T^{e q}$, その 1 周期に占める弾性応 
答時間の $1 / 2$ を $t_{e}$, 任意の時刻を $t$ とする。塑性負荷・弾性除荷, 応答の負側・正側を組み合わせた 4 つの状態を考えると, 状態遷移 時の $\bar{Q}$ は一意に求まる (Fig. 4 の点 $\mathrm{a}, \mathrm{b}, \mathrm{c}, \mathrm{d}$ )。これらの間を直線で 補間して近似した床応答加速度は, 以下のようになる。

(Positive plastic loading: state I)

$$
\bar{Q}=-(\bar{\alpha}-2)+\frac{2(\bar{\alpha}-1)}{T^{e q} / 2-t_{e}} t \quad \text { for } \quad 0 \leq t<T^{e q} / 2-t_{e}
$$

(Positive elastic unloading: state II)

$$
\bar{Q}=\bar{\alpha}-\frac{2}{t_{e}}\left\{t-\left(\frac{T^{e q}}{2}-t_{e}\right)\right\} \quad \text { for } T^{e q} / 2-t_{e} \leq t<T^{e q} / 2
$$

(Negative plastic loading: state III)

$$
\bar{Q}=(\bar{\alpha}-2)-\frac{2(\bar{\alpha}-1)}{T^{e q} / 2-t_{e}}\left(t-\frac{T^{e q}}{2}\right) \quad \text { for } \quad T^{e q} / 2 \leq t<T^{e q}-t_{e}
$$

(Negative elastic unloading: state IV)

$$
\bar{Q}=-\bar{\alpha}+\frac{2}{t_{e}}\left\{t-\left(T^{e q}-t_{e}\right)\right\} \quad \text { for } \quad T^{e q}-t_{e} \leq t \leq T^{e q}
$$

非減衰系の場合, 復元力は絶対加速度の時刻歴波形に相似であり, 式(6)や Fig. 4 は床応答加速度を近似したことになる。以上の方法は, 概念的には, Den Hartog が固着と滑りを伴う摩擦系の矩形型復元力 を Fourier 級数展開して応答を求めた方法 ${ }^{8}$ に近いものである。

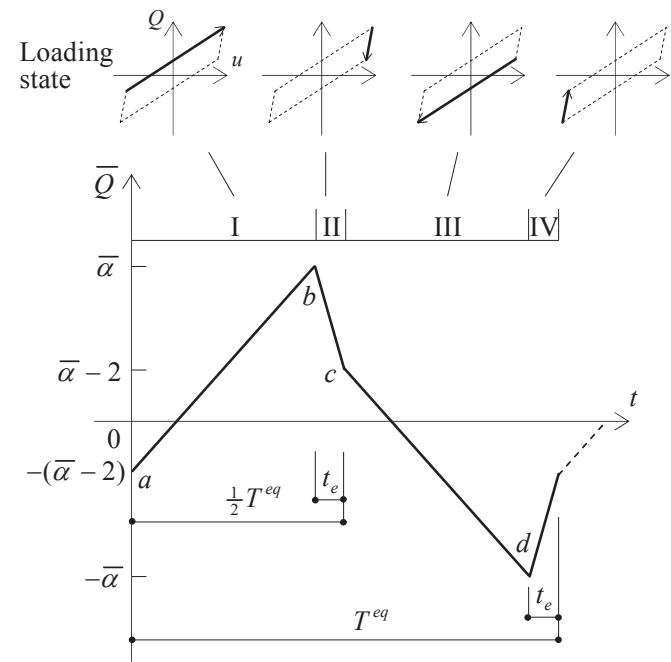

Fig. 4 Piecewise linear approximation of floor acceleration

\section{2 1 サイクルにおける弾性応答時間}

前述した近似応答を定めるには, 弾性応答時間 $t_{e}$ を定めなければ ならない。本来， $t e$ の評価には, 時刻歴解析結果が必要である。一 方, 時刻歴解析を介さない高調波の予測が本研究の目的であるから, $t_{e}$ を 2 次剛性比 $p$ と塑性率 $\mu$ の 2 変数のみで評価することを考える。 半サイクルに占める塑性負荷状態の時間の比率を $\tau$ とする。この $\tau$ を用いて， $t_{e}$ を次のように示す。

$$
t_{e}=\frac{T^{e q}(1-\tau)}{2}
$$

つぎに, Caughey の等価線形化手法と同様に, 建物の変位応答波形 が正弦波で近似できるとする。この変位応答波形の幾何学的関係か
ら，塑性率 $\mu$ を用いて， $\tau$ は以下のように近似できる。

$$
\tau \approx 1-\frac{1}{\pi} \cos ^{-1}\left(\frac{\mu-2}{\mu}\right)
$$

さらに, 式(8)は, 広範な大小の $\mu$ に対して, 高い精度を保持したま ま，以下の近似が可能である。

$$
\tau \approx 1-\frac{2}{\pi} \frac{1}{\sqrt{\mu}}
$$

この近似式を式(7)に代入し直せば，既知量から $t_{e}$ が次式で求まる。

$$
t_{e}=\frac{T^{e q}}{\pi \sqrt{\mu}}
$$

式(10)からわかるように，变位応答波形を正弦波で近似した結果，2 次剛性比 $p$ が変化しても， $t_{e} / T^{e q}$ の值は一定となる。

2 次剛性比 $p$ と塑性率 $\mu$ が既知であれば，式(5)と式(10)を式(6)に 代入することにより, 多直線近似した床応答加速度は, 位相を除け ば一意に定まる。 $T^{e q}$ については, 建物の弾性時固有周期 $T, p$ およ び $\mu$ から求まる。

\section{3 数值計算例}

式(1)の非線形時刻歴解析により求めた床応答加速度と，その塑性 率および式(6)から床応答加速度の近似を求めた結果を Fig. 5 に示す。 ここでは, 2 種類の 2 次剛性比 $p$ に対して, 塑性率 $\mu$ がその目標值 10 に合致するように地動の振幅を調整した。また，多直線近似の応 答の位相は, 降伏時の時刻が元の応答のそれと一致するように定め た。図からは， $p=0.15$ の場合， 2 つの応答の差が若干認められる ものの, $t_{e}$ の時間の長さを含め, 応答の形状は概敞対応している。

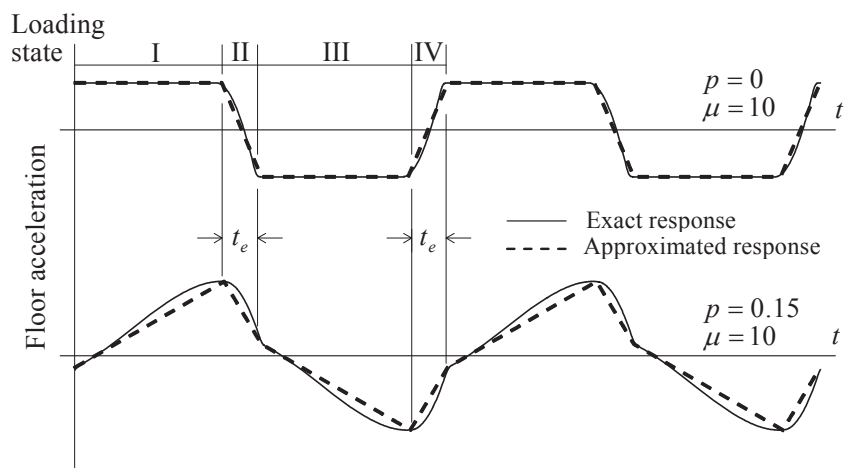

(above: elastic perfectly plastic system, below: bilinear system) Fig. 5 Comparison of two different floor acceleration

\section{4 . 床応答加速度に含まれる高調波の振幅の簡易評価法}

\section{1 床応答加速度の Four ier 変換}

第 3 章で近似した床応答加速度を Fourier 変換することにより，2 次剛性比や塑性率と高調波成分の関係を明らかにする。

床応答加速度の複素 Fourier 係数は, 次のように定義される。

$$
\begin{aligned}
& F_{k}=\frac{1}{T^{e q}} \int_{0}^{T^{e q}} \bar{Q}(t) \exp \left(-i \cdot 2 \pi k t / T^{e q}\right) \mathrm{d} t \\
& \bar{Q}(t)=\lim _{n \rightarrow \infty} \sum_{k=-n}^{n} F_{k} \exp \left(i \cdot 2 \pi k t / T^{e q}\right)
\end{aligned}
$$

ここに, $i$ は虚数単位， $F_{k}$ は第 $k$ 高調波に対する複素 Fourier 係数 である。区分定義される式(6)を式(11a)に代入して，それぞれの積分 解を結合する。この解に式(7)を代入し, 複素 Fourier 係数 $F_{k}$ の閉解 を次のように得る。 


$$
F_{k}=\left\{\begin{array}{cl}
2 \frac{1-(1-\tau) \bar{\alpha}-\{1-(1-\tau) \bar{\alpha}-2 \tau\} \exp (i k \pi \tau)}{(k \pi)^{2}(1-\tau) \tau} & \text { for } k \in \text { odd } \\
0 & \text { for } k \in \text { even }
\end{array}\right.
$$

$k$ が奇数と偶数で式(12)が場合分けされている理由は, その原形に は，全体に係る $1-\exp (i k \pi)$ の項が存在するためである。その結果， 良く知られるように, 高調波の偶数次成分は零となる。式(12)を 2 倍した值の絶対值をとれば，高調波の有限 Fourier 係数 $A_{k}$ を得る。

$$
A_{k}=4 \frac{|1-(1-\tau) \bar{\alpha}-\{1-(1-\tau) \bar{\alpha}-2 \tau\} \exp (i k \pi \tau)|}{(k \pi)^{2}(1-\tau) \tau} \quad \text { for } k \in \text { odd }
$$

さらに，式(13)に含まれる指数関数を三角関数に置き換えて，式を 整理したものが次式である。

$$
A_{k}=\frac{4 \sqrt{r^{2}-2 \rho r s+s^{2}}}{(k \pi)^{2}(1-\tau) \tau} \quad \text { for } k \in \text { odd }
$$

ここに， $r, s$ および $\rho$ は，それぞれ以下のように定義される。

$$
\begin{gathered}
r=1-(1-\tau) \bar{\alpha}, \quad s=1-(1-\tau) \bar{\alpha}-2 \tau \\
\rho=\cos (k \pi \tau)
\end{gathered}
$$

2 次剛性比 $p$ と塑性率 $\mu$ が指定されれば, 式(5)と式(9)を代入した 式(14)から高調波の Fourier 係数 $A_{k}$ が推定できる。しかしながら， 後述するように，床応答を巨視的に多直線近似した結果，若干の問 題が生じることに加え, 式も複雑で直感的に理解しづらい。そこで, 式(14)をさらに式展開することにより，これらの問題を解決する。

\section{2 高調波の振幅の評価式の近似}

式(14)と式(15)の表現から, 式(14)の分子には $p$ に関する高次項が 含まれることがわかる。いま, 対象とする 2 次剛性比 $p$ を高々 0.5 程度と考えると, この高次項を無視できる。なお, 架構に対してダ ンパーの負担力が小さい制振建物では，より大きな $p$ が考えられる が，線形に近い系では高調波の存在が顕著ではない。そのため,こ の近似が建物の対象範囲を狭めるわけではない。以上の近似を用い て式(14)を整理した式は，以下の平易な形となる。

$$
A_{k} \approx \frac{2 \sqrt{2 \mu}}{k^{2} \pi} \sqrt{1+\cos (k \pi \cdot \tau(\mu))} \quad \text { for } k=3,5,7,9, \ldots
$$

\section{3 塑性率が小さな範囲における高調波の評価式の修正}

床応答を多直線近似した弊害として, 塑性率 $\mu$ が 1 よりも大きな 值で $A_{k}$ は極小值を迎えてしまう（Fig. 6)。これより小さい $\mu$ におい て, 式(16)は物理的な意味をなさない。本節では, これを経験的に 改善することにする。

式(16)によって $A_{k}$ の極小值を与える $\mu$ は，以下の值となる。

$$
\underset{\mu}{\arg \min } A_{k}=(k / \pi)^{2}
$$

この $\mu$ よりも小さな範囲での $A_{k}$ の物理的意味は希薄である。その ため, 降伏時 $(\mu=1) て ゙ ~ A_{k}=0$ となるように, 式(17)の結果を用いて 式(16)の原点を移動した次式を提案する。

$$
\frac{A_{k}}{\bar{\alpha}} \approx \frac{2 \sqrt{2 \mu^{\prime}}}{k^{2} \pi} \frac{\sqrt{1+\cos \left(k \pi \cdot \tau\left(\mu^{\prime}\right)\right)}}{1+p\left(\mu^{\prime}-1\right)}, \quad \begin{aligned}
& \mu^{\prime}=\mu+\left(\frac{k}{\pi}\right)^{2}-1 \\
& \text { for } k=3,5,7,9, \ldots
\end{aligned}
$$

ここで, $A_{k} / \bar{\alpha}$ は床応答加速度をその最大值(ZPA)で基準化した波に 含まれる高調波振幅の意味を持つ。以上の修正は厳密性に欠けるも
のの，そもそもの応答の多直線近似が経験的であることから，この 方法を採用した。

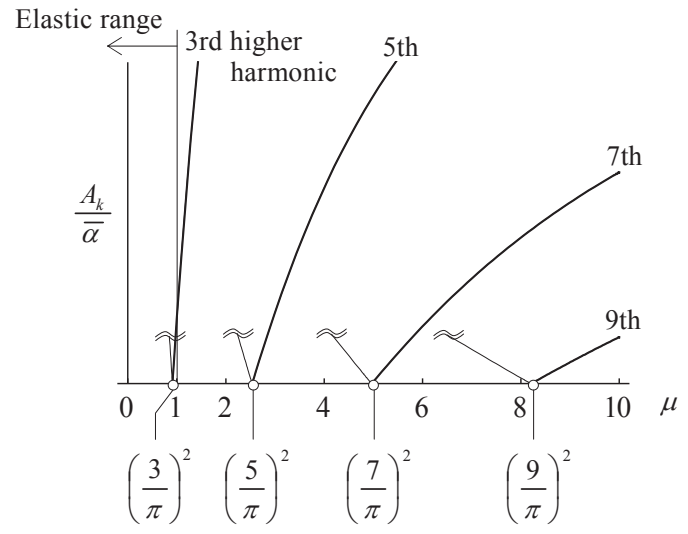

Fig. 6 Modification of evaluation of higher harmonics in small range of ductility factor $(p=0)$

\section{5。時刻歴応答解析による高調波の評価式の精度検証 \\ 5.1 検討条件}

本章では, Table 1 に示寸様々な 2 次剛性比 $p$ を有する系を対象と し，式(18)による評価精度を検証する。降伏せん断力係数 $\alpha_{y}$ を 0.03 $\sim 0.25$ の範囲で設定し, 弾性時の固有周期 $T$ が概ね $0.4 \sim 1$ 秒になる よう, 降伏変位を固定する。内部減衰定数 $h$ は, 0 と 0.02 の 2 通り とする。地動の周期を 1 秒に固定し，100 までの塑性率を得るよう に, 地動加速度の振幅を降伏せん断力係数で除した制御变数を漸増 する。また，地動の継続時間は 200 秒とする。

時刻歴応答解析による床応答加速度を最大值(ZPA)で基準化した 波を Fourier 変換して求めた Fourier 振幅と予測值 $A_{k} / \bar{\alpha}$ を比較する。 式(18)による予測には，時刻歴解析により得られた最大塑性率 $\mu$ を 用いる。時刻歴解析では, 輝線スペクトルを連続スペクトルに歪め ないよう，定常状態と見做せる区間内でゼロ・クロッシング法 ${ }^{11)} に$ より，等価固有周期の整数倍の区間をサンプリングし，空関数を通 さずにこれをFourier 変換する。また, 過渡応答区間で応答が最大值 を迎えたり正負片側へドリフトしたりしないように，時刻歴解析に 用いる地動には振幅包絡関数を乗じて配慮する。

\section{2 高調波の振幅の比較}

時刻歴応答解析による值と式(18)による予測值を比較したものを Fig. 7 に示す。上段から順番に第 3 , 第 5 , 第 7 および第 9 高調波の 結果を掲載している。両者の值は, 小さい領域から大きな領域まで 広範の塑性率 $\mu$ に対して合致している。両者とも，高調波の次数 $k$ が高くなるほど，また， 2 次剛性比 $p$ が大きくなるほど，高調波の 振幅 $A_{k}$ は小さくなる。ただし, 第 3 高調波に限定した場合, $\mu$ が 2 程度までは， $p$ が $A_{k}$ に与える影響は小さい。時刻歴計算で 2 以下 の層の塑性率が求められる高層建物は，この範疇である。また，塑

Table 1 Post-yield stiffness ratio in numerical example

\begin{tabular}{cl}
\hline Parameter & \multicolumn{1}{c}{ Corresponding building type } \\
\hline$p=0.01$ & Frames with friction damper \\
\hline$p=0.05$ & Benchmark structures \\
\hline$p=0.15$ & Frames isolated by lead rubber bearing \\
\hline$p=0.3$ & Frames with steel damper \\
\hline
\end{tabular}



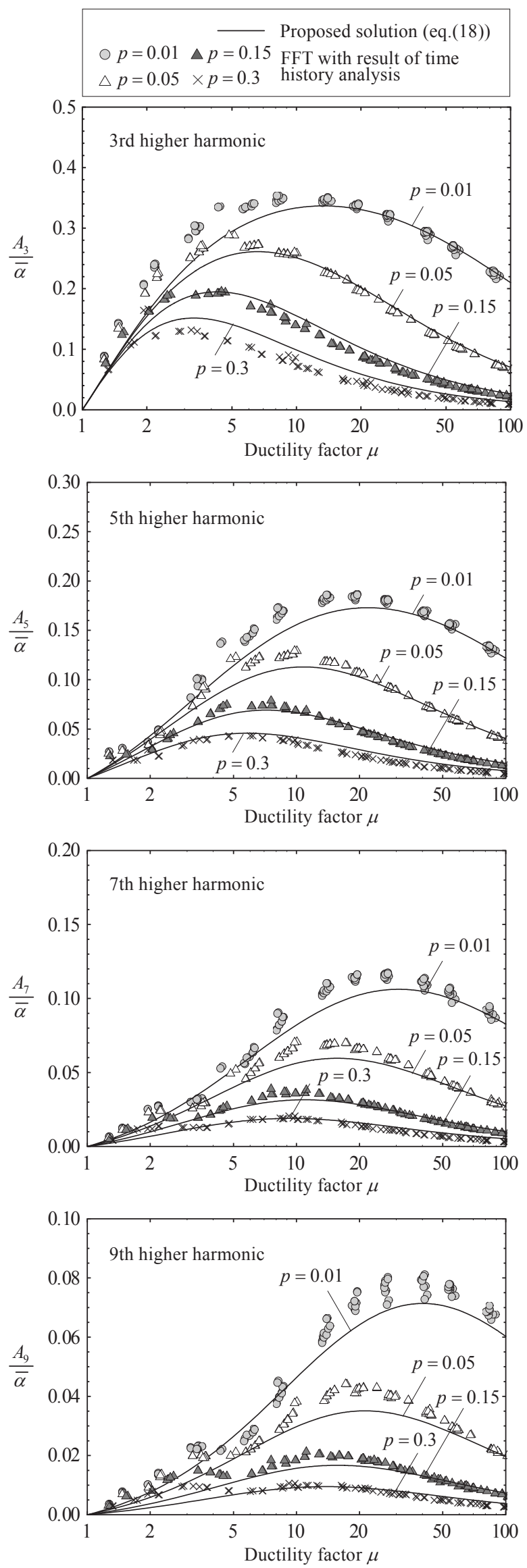

Fig. 7 Comparison of Fourier amplitude of higher harmonics (time history analysis vs. proposed solution)
性率の増大に伴い，高調波の振幅は成長していくものの，ある值以 上では，高調波の振幅は減少する。高調波の振幅が極大点を迎える 塑性率 $\mu$ は， $p$ が小さいほど, また高調波の次数が高いほど大きな 值となる。予測值は，これらの特徵を極めて良く表現している。

6. まとめ

非構造部材の設計用地震力を議論するための予備研究として, 調 和地動を受けるバイリニア型履歴特性を有する 1 質点系の床応答加 速度に含まれる高調波成分を分析した。結論を以下に要約する。

1) 定常状態における建物の時刻歴絶対加速度を多直線近似し, その 近似応答は建物の 2 次剛性比（初期剛性に対寸る降伏後の接線剛 性の比）と塑性率により一義的に決定されることを示した。

2) 多直線近似した絶対加速度応答を Fourier 変換し, 高調波の振幅 の閉解表現を理論的に誘導した。これは, 建物の 2 次剛性比およ び塑性率により表される。さらに, 2 次剛性比が取り得る範囲を 踏まえ, この解に含まれる 2 次剛性比に関寸る微小項を無視し, 高調波振幅の閉解をより簡易な式に近似した。

3) 非線形時刻歴解析による床応答加速度を離散 Fourier 変換した結 果と誘導した理論解を比較し, 第 3 高調波から第 9 高調波まで, 両者が極めて良く一致することを確認した。

建物応答の極值分布を仮定すれば、広帯域の振動数成分を有する 地震動を入力とする問題に本知見を適用できると考える。

参考文献

1) Kenchikubutsu no kozokankei gijutsukijun kaisetsusho henshu iinkai: Kenchikubutsu no kozokankei gijutsukijun kaisetsusho 2015 nendoban, Zenkoku kampo hanbai kyodo kumiai, 2015.

建築物の構造関倸技術基準解説書編集委員会: 建築物の構造関係技術基 準解説書 2015 年度版, 全国官報販売共同組合, 2015

2) J. Lin And S. Mahin: Seismic response of light subsystems on inelasitc structures, Journal of Structural Engineering, ASCE, Vol. 111, pp.400-417, 1985.

3) I. Politopoulos and C. Feau: Some aspects of floor spectra of 1DOF nonlinear primary structures, Earthquake Engineering and Structural Dynamics, pp. $975-993,2007$.

4) K. Sato, T. Ishihara, K. Suzuki and M. Nagano: Study on approximate estimation for non-linear floor response spectra of multi-story buildings for artificial ground motions, Summaries of Technical Papers of Annual Meeting Architectural Institute of Japan, B-1, pp.869-870, 2016.8 (in Japanese).

5) K. Kaneko: Direct evaluation method of floor response spectra from specified ground response spectra based on spectrum difference rule, Journal of Structural and Construction Engineering (Transactions of AIJ), No.729, pp.1789-1797, 2016.11 (in Japanese).

6) T. Caughey: Sinusoidal excitation of a system with bilinear hysteresis, Journal of Applied Mechanics Division, ASME, Vol.27, pp.640-643, 1960.12.

7) P. C. Jennings: Periodic response of a general yielding structure, Journal of the Engineering Mechanics Division, Proceeding of the ASCE, Vol.90, pp.131-166, 1964.4.

8) J. P. Den Hartog: Forced vibrations with combined Coulomb and viscous friction, Transaction of the ASME, pp.107-115, 1931.

9) B. Westermo and F. Udwadia: Periodic response of a sliding oscillator system to harmonic excitation, Earthquake Engineering and Structural Dynamics, Vol. 11, pp.135-146, 1983.

10) W. D. Iwan: The dynamic response of bilinear hysteretic systems, Thesis presented to the California Institute of Technology, 1961.

11) Y. Osaki: Shin Jishindo no supekutoru kaiseki nyumon, Kajima shuppankai, 1994.

大崎順彦: 新・地震動のスペクトル解析入門, 鹿島出版会, 1994 


\section{HIGHER HARMONICS OF FLOOR ACCELERATION IN SDOF SYSTEM WITH BILINEAR HYSTERESIS UNDER PERIODIC SINUSOIDAL GROUND MOTION}

\section{Kensaku KANEKO*}

* Assist. Prof., School of Environment and Society, Dept. of Architecture and Building Engineering, Tokyo Institute of Technology, Dr. Eng.

This research is a preliminary study to evaluate the seismic force of nonstructural components (secondary system) beyond the elastic limit of steel buildings. The objective of this paper is to propose a convenient evaluation method of higher harmonics in a periodic response of an SDOF system with bilinear hysteresis subjected to sinusoidal ground motion.

Firstly, numerical examples are demonstrated to show how the higher harmonics in a floor response affects the acceleration response of the secondary system. Two types of floor acceleration are considered. One is waveform obtained by nonlinear time history analysis and the other is a sinusoidal waveform having the same amplitude. The result shows that secondary response to these floor acceleration are significantly different if the frequency ratios of the secondary system to the input motion are close to or coincide with odd numbers.

Secondary, this critical higher harmonics are formulated by specified dynamic characteristics of the building and its peak displacement. In order to simplify the formulation, floor acceleration waveform in the steady state condition is approximated using piecewise linear waveform defined by a post-yield stiffness ratio and a ductility factor. A closed form of Fourier coefficients of the higher harmonics is derived with respect to the approximated waveform. Furthermore, the solution is simplified by neglecting higher terms in the exact solution with respect to the post-yield stiffness ratio for practical application.

Finally, the proposed solution is compared with the result obtained by discrete Fourier transform in time history analysis. The maximum ductility factor is assumed to be 100 in a numerical example. The post-yield stiffness ratio is in the range of 0.01 to 0.3 , depending on the type of structures. The ninth higher harmonic is analyzed at most. The results show a good accuracy of the proposed solution in a wide variety of ductility factors. 